DOI: $10.7256 / 1812-8696.2013 .05 .10$

\title{
S НАШИОНАЛЬНЫЙ ВОПРОС
}

\section{А.А. Болтаевский}

\section{БОЛГАРСКИЙ ОККУПАЦИОННЫЙ РЕЖИМ В СЕРБИИ В 1916 - 1918 гг.}

\begin{abstract}
Аннотация: B статье анализируются действия болгарских властей в Македонии в 1916 - 1918 г2., во многом объяснявшиеся идеей создания «Великой Болгарии». Автор показывает, что сталкивающиеся в этом регионе интересы балканских государств заставляли их проводить во многом схожую политику «этнических чисток», которые оправдывались стремлением к завериению национального объединения, политика насильственной болгаризации Македонии явилась продолжением политики сербизации, проходивщей перед этим. Фактически Сербия и Болгария пользовались одинаковыми методами ради достижения в общем-то схожей иели: закрепления македонского края в своем составе.
\end{abstract}

Ключевые слова: История, наџиональные отношения, Балканы, этнические чистки, Сербия, Македония, Болгария, Первая мировая война, оккупационный режим, Гаагская конвенция

$\mathrm{B}$ начале XX в. Македония, отличавшаяся пестрым составом населения - македонцы - славяне (часть славян позднее стала относить себя к болгарам, а другая к сербам), турки, греки, румыны и албанцы, была ареной разнообразных этнических конфликтов. При этом, как отмечал посетивший Балканы в начале войны и ставший впоследствии знаменитым американский журналист Д. Рид, характерной особенностью местных жителей являлась их ненависть к ближайшим иноземцам ${ }^{1}$. Известна притча о вражде между во многом родственными, в том числе и в конфессиональном плане, балканскими народами: как-то одному балканцу пообещали: то, что он пожелает у себя, тотчас удвоится у других; уточнив, что это распространяется и на брата, он сразу ответил: «Выколите мне один глаз»². Банальная жестокость этой фразы наглядно демонстрирует отношения между вековыми соседями в Юго-Восточной Европе.

\footnotetext{
${ }^{1}$ Рид Д. Вдоль фронта (Война на Восточном фронте). М. Л., 1928. С. 322.

${ }^{2}$ Марков Г. Балканы и «балканизация». Историческая судьба балканских народов в XX веке // Человек на Балканах в эпоху кризисов и этнополитических столкновений XXв. / Отв. ред. Г. Литаврин, Р. Гришина. М., 2002. С. 26.
}

«Македонская проблема превратилась в один из самых жизненных международных вопросов, потому что здесь, как в фокусе, скрестились сложные и противоречивые интересы Европы», констатировал в 1915 г. профессор А. Л. Погодин ${ }^{3}$. А уже упомянутый выше Д. Рид отмечал: «Македонский вопрос был причиной каждой крупной европейской войны за последние 50 лет, и пока он не будет разрешен, не будет прочного мира на Балканах, ни за пределами их» ${ }^{4}$

Как известно, по условиям Бухарестского мирного договора 10 августа 1913 г. Македония была поделена между Сербией, к которой отошла большая ее часть - Вардарская, и Грецией. Только небольшая территория осталась в составе Болгарии, правители которой, однако, не собирались так просто расставаться со своими землями. Фердинанд Кобургский и его окружение строили планы создания великой Болгарии, согласно которым страна должна была омываться всеми морями Балканского полуострова: Черным, Белым и Синим 5 , да и сам болгарский народ был

\footnotetext{
${ }^{3}$ Погодин А.Л. Русская политика на Ближнем Востоке, чем она была и чем должна бы быть / История Великой войны. М., 1915. T. 1. С. 275.

${ }^{4}$ Рид Д. Указ. соч. С. 306.

${ }^{5}$ Белым морем называлось Эгейское, а Синим - Адриатическое.
} 


\section{Политика и общество $5(101) \cdot 2013$}

искренне убежден, что население Македонии - болгары ${ }^{6}$. Позднее С. Д. Сазонов отмечал: «Бухарестский мир был только пластырем, налепленным на незалеченные балканские язвы, которым было суждено вскрыться не далее чем через год» ${ }^{7}$.

Глава болгарского правительства В. Радославов говорил, что «Болгария не отказывается, и не скрывает этого, от своих исторических и этнографических прав, она не может без Македонии и Каваллы... Болгария будет с теми, кто гарантирует ее права на них» ${ }^{8}$. В планах болгарского высшего политического руководства было и присоединение «балканского Парижа» - города Салоники и даже Царь-града - Константинополя.

Осенью 1914 г. Балканы оказались в центре внимания враждебных коалиций, каждая из которых стремилась найти там союзников. Сербская армия ценой героических усилий противостояла австро-венгерским силам, но основной ее задачей могла быть только упорная оборона до победы Антанты на главных фронтах 9 . Почти сразу после начала боевых действий временной столицей Сербии стал Ниш, куда вынуждены были перебраться как королевская семья, так и правительственные учреждения ${ }^{10}$.

Положение Македонии было неопределенным Сербское правительство, по сути, установило там оккупационный режим, переименовав при этом в «Южную Сербию». В ряде македонских областей близ албанской границы еще осенью 1913 г. происходили волнения против политики принудительной сербизации.

Базировавшиеся на территории Болгарии четы Внутренней Македонской Революционной Организации с началом войны устраивали налеты и диверсии в Вардарской Македонии. Сербское командование считало македонских солдат настолько ненадежными, что использовало, в основном, для тыловой службы ${ }^{11}$. В конце 1914 г. сербское правительство заявляло, что «предпочитает оставить всю Сербию австрийцам, чем

\footnotetext{
${ }^{6}$ Погодин А.Л. Указ. соч. С. 275; Сербия и Черногория. М., 1914. C. 7.

${ }^{7}$ Сазонов С. Д. Воспоминания. М., 1991. С. 80.

${ }^{8}$ Цит. по: Шкундин Г. Д. Динамика болгарских военно-политических целей в ходе Первой мировой войны / Первая мировая война и проблемы политического переустройства в Центральной и Юго-Восточной Европе. М, 1991. С. 18.

9 Зайончковский А. М. Первая мировая война. М., 2002. С. 82.

${ }^{10}$ Сербия и Черногория. С. 4.

${ }^{11}$ История Югославии. Т. 1. М., 1963. С. 665.
}

уступить клочок Македонии болгарам» ${ }^{12}$. В свою очередь, уничтожение самостоятельной Сербии, стоявшей на пути к Салоникам, было необходимо германскому блоку.

Сербские позиции осложнялись почти откровенной враждебностью соседних Болгарии и Греции. Хотя непосредственным противником Греции являлась Болгария, против которой действовал греко-сербский оборонительный союз, однако по отношению к Сербии греческое правительство претендовало на район города Монастира, а также на Северный Эпир, включенный в состав Албании ${ }^{13}$. Германия готова была передать эти территории, требуя от Греции лишь нейтралитета. Антанте, в свою очередь, необходимо было присоединение Греции к военным действиям против Центральных держав. Это в конечном итоге определяло греческую позицию.

Позиция русского посла в Константинополе М. К. Гирс заключалась в том, что только территориальными жертвами в пользу Болгарии можно помешать ее союзу с Австро-Венгрией ${ }^{14}$. Эта точка зрения нашла свое отражение в российском министерстве иностранных дел: Сербии было предложено уступить Болгарии Македонию по линии 1912 г. На это решение помимо тяжелого положения на фронте повлияло, по всей вероятности, нежелание обострять отношения с Болгарией, которая входила в сферу интересов России.

Царь Фердинанд и его окружение, получая финансовую помощь, как от Германии, так и от Франции, занимали выжидательную позицию до лета 1915 г. $^{15}$, когда в противостоянии казалось наметился перелом в пользу Центральных держав. Германия обещала Болгарии за вступление в войну на своей стороне Вардарскую Македонию и часть Поморавской Сербии, кроме того, небольшой участок в районе Марицы передавала Турция. К моменту вступления Болгарии в войну была

\footnotetext{
${ }^{12}$ Царская Россия в мировой войне. Л., 1926. С. 87. № 422.

${ }^{13}$ Архив внешней политики Российской империи (АВПРИ). Ф. 151. Оп. 482. Д. 3871. Л. 8 б; Корсун Н.Г. Балканский фронт мировой войны. 1914 - 1918. М.,1939. С. 13.

${ }^{14}$ Международные отношения в эпоху империализма. Документы из архивов царского и Временного правительств. Серия 3. 1914 - 1918. Т. VI. Ч. 1. М. - Л., 1935. С. 436. № 424.

15 Однако еще до вступления Болгарии в войну произошла так называемая Валандовская афера - вооруженная акция для взрыва моста на реке Вардар с целью пресечь пути снабжения Сербии военными грузами через Грецию.
} 
даже сформирована дивизия в 30 тыс. человек из беженцев - македонцев для борьбы против сербов ${ }^{16}$.

Таким образом, в сентябре 1915 г. образовался Четверной союз, резко изменивший положение на Балканах не в пользу Антанты.

России приходилось считаться с подобной ситуацией, что ставило задачу освобождения болгарского народа от господства Кобургской династии. Считалось, что главным итогом победоносной войны должно быть окончательное освобождение и объединение славянства, и создание «Великой Сербии» и «Великой Болгарии». В состав последней предполагалось включить сербскую и греческую (Эгейскую) части Македонии ${ }^{17}$. В августе 1916 г. начальник штаба Верховного главнокомандующего генерал М. В. Алексеев в обход Греции и Сербии предполагал передать Болгарии Македонию до Вардара, Каваллу и даже Салоники в обмен на низложение Фердинанда и разрыв с Германией ${ }^{18}$.

Осенью 1915 г. под давлением превосходящих сил $^{19}$ сербская армия была вынуждена оставить свою страну и после тяжелых переходов ее остатки, численностью около 120 тыс. человек, были эвакуированы на остров Корфу ${ }^{20}$. Началась сербская Голгофа. Страна была поделена между Австро-Венгрией и Болгарией по реке Мораве. При этом между ними возникли существенные разногласия в Косово и Метохии, так как болгарские власти отказывались передавать Дунайской монархии занятые ими Приштину, Призрен, Эльбасан. В итоге в качестве третейского судьи пришлось выступить Германии.

На занятых территориях к востоку от реки Моравы болгарские власти создали генерал-губернаторство Поморавье с центром в городе Ниш, а в Вардарской Македонии возникло Македонское генерал-губерна-

\footnotetext{
${ }^{16}$ См.: Гринберг С. Ш. Первая мировая война и болгарский народ / Исторические записки. Т. 21. М., 1947.

${ }^{17}$ Ястребов Н. В. Славянская сторона Великой войны 1914 1915 гг. / История Великой войны. М., 1915. Т. 2. С. 9.

${ }^{18}$ Косик В.И. Гордиев узел Балкан / Македония: проблемы истории и культуры. М., 1999. С. 69.

19 «Болгарские дивизии по численному составу пехоты были настоящими армейскими корпусами, но их артиллерия была слабой». - Подполковник Лярше. Некоторые статистические данные войны 1914 - 1918 гг. // Военный зарубежник. 1934. № 12. С. 121.

${ }^{20}$ История Югославии. Т. 1. М., 1963. С. 668.
}

торство. При этом в Македонии часть жителей встречала болгарских солдат как освободителей с цветами и овациями ${ }^{21}$.

Управление в Македонии осложнялось определенной двойственностью: наряду с военными властями были назначены гражданские чиновники без ясного и точного разграничения функций между ними, что делало неизбежными конфликтные ситуации ${ }^{22}$.

Оккупационными силами был установлен жесточайший режим, нарушавший многие пункты Гаагской конвенции. Местное мужское население использовалось на принудительных работах в Болгарии, например на строительстве железных дорог. Уже в конце 1915 г. было отдано распоряжение отправить в Болгарию все мужское население от 15 до 70 лет из округов Велеса, Пореча и Прилепа, против чего выступил даже болгарский епископ ${ }^{23}$. С высланными отмечалось крайне суровое обращение: наряду с минимальными пайками (кукурузный суп с 60 г. кукурузного хлеба) наблюдался недостаток в одежде ${ }^{24}$. Среди мужчин проводились рекрутские наборы, вызывавшие недовольство населения ${ }^{25}$. В 1916 г. болгарские власти в Македонии мобилизовали мужчин в возрасте от 18 до 32 лет, а в 1917 г. от 32 до 45 лет, однако вследствие дезертирства реальное пополнение составило только половину от ожидаемого числа людей. Часть мобилизованных отправилась при этом в расположение турецких войск в Палестине ${ }^{26}$.

Об отношении к македонскому населению говорит тот факт, что в январе 1916 г. болгарские власти реквизировали почти все продовольствие у местных жителей, фактически обрекая их на голодное существование ${ }^{27}$.

С пропагандистскими целями в Охриде всем нотаблям было предложено подписать заявление о том, что

${ }^{21}$ Терзиев В. Българският характер на славянскато население в Македония. София, 1995. С. 84.

22 Дневници (стенографски) на XVII-то обыкновенно народно собрание. Втора рядовна сесия. Открыта на 14 декемврий 1915 г., закрыта на 15 марта 1916 г. София, 1928. С. 329.

${ }^{23}$ Насильственное выселение жителей из оккупированных областей Сербии. Одесса, 1917. С. 6.

${ }^{24}$ Сербия под врагом. Официальные документы и нота сербского правительства. Одесса, 1917. С. 29.

${ }^{25}$ Насильственное выселение жителей из оккупированных областей Сербии. С. 12.

${ }^{26}$ История македонского народа. Скопье, 1986. С. 228.

27 Там же. С. 231. 


\section{Политика и общество $5(101) \cdot 2013$}

они терроризировались сербскими властями, а теперь желают стать болгарскими подданными ${ }^{28}$.

Оккупационные власти установили два новых налога, один из которых был уже существовавший при турках налог на скот ${ }^{29}$. Подобные меры привели к резкому ухудшению уровня жизни местного населения. Кроме того, признавалась имуществом, оставшимся без хозяина, любая собственность, принадлежащая лицам, убитым во время боевых действий или интернированным ${ }^{30}$.

Началась политика насильственной болгаризации Македонии. Интернированию подверглась большая часть интеллигенции: священники, учителя, врачи, гражданские чиновники, размещенные в лагерях в Софии, Филиппополе, Рущуке, Адрианополе ${ }^{31}$. На их место были присланы болгарские священники и учителя. В школах насаждался болгарские языки и национально-патриотические песни, широко отмечались болгарские праздники ${ }^{32}$. Одновременно в 1916 г. ряд болгарских ученых посетил с научной экспедицией Македонию и Поморавию.

Изымались сербские книги, рукописи, карты, гравюры. Характерный пример: в апреле 1916 г. болгарское министерство торговли решило все собранные книги отсылать в национальную типографию, где они использовались в качестве макулатуры для изготовления бумаги ${ }^{33}$. Летом 1916 г. началась замена фамилий: вместо сербского окончания -ич устанавливалось болгарское -ов ${ }^{34}$. Между прочим, подобные меры принимались и в Болгарии Т. Живкова, например, смена турецких имен на болгарские во время так называемого «Возродительного процесса».

На протяжении 1915 - 1918 гг. болгарские власти применяли террор к местным жителям, в том числе убийства лиц, подозреваемых в сочувствии к сербам.

${ }^{28}$ Сербия под врагом. С. 28.

29 Там же. С. $49-50$.

30 Там же. С. 35.

${ }^{31}$ Там же. С. 20, 29.

32 До этого сербскими властями были аналогично закрыты все болгарские школы. - Дневници (стенографски) на XVII-то обыкновенно народно собрание. Втора рядовна сесия. С. 224.

${ }^{33}$ Сербия под врагом. С. 77.

${ }^{34}$ Насильственное выселение жителей из оккупированных областей Сербии. С. 18 - 19.
Так только в Велесском и Прилепском районах было убито около 2 тыс. человек ${ }^{35}$.

Следует отметить, что не меньшие злоупотребления (в частности, реквизиция продовольствия и разного рода имущества) осуществляли, не считаясь с болгарской администрацией, германские солдаты и офицеры. Глава Македонского генерал-губернаторства Р. Петров сообщал, что «другие являются господами на оккупированных нашей армией землях» ${ }^{36}$.

Подобная политика болгарских властей привела к многочисленным возмущениям. В феврале - марте 1917 г. в районе Топлицы вспыхнуло выступление четников и крестьян, раскинувшееся на территории с населением до 1 млн. человек. Вскоре оно перекинулось и на австро-венгерскую зону оккупации. Карательная экспедиция, в состав которой вошли болгарские, австро-венгерские и немецкие части, используя артиллерию и самолеты, сумела разбить повстанцев ${ }^{37}$. Несмотря на это, волнения не утихали вплоть до лета 1918 г. О жестокости карателей говорит тот факт, что когда болгарский офицер сообщил в штаб о численности захваченных восставших, ему был задан вопрос, о том не сколько захвачено, а сколько расстреляно ${ }^{38}$

Общие потери Сербии в Первой мировой войне составили примерно 1180 тыс. человек или $24 \%$ населения, что, по мнению сербских исследователей, создает угрозу национальному исчезновению. От голода и болезней в концлагерях погибли свыше 800 тыс. детей, женщин и стариков. Позднее сербское правительство сообщало о 2400 военных преступлениях, совершенных только болгарами ${ }^{39}$. Вина за эти жертвы лежит на Четверном союзе, а также на странах Антанты, которые вследствие своих узко стратегических целях не смогли вовремя оказать должную помощь своей союзнице.

Подведем некоторые итоги. Как отмечал Васил Коларов, «Македония, угнетенная и порабощенная, была всегда причиной несогласий между балканскими государствами, желание владеть ею много раз вызывало военный пожар, который опустошил полуостров и

\footnotetext{
${ }^{35}$ История македонского народа. С. 233.

${ }^{36}$ Влахов T. Отношенията между България и Централните сили по време на войните 1912 - 1918 г. София, 1957. С. 243.

${ }_{37}$ Писарев Ю. А. Оккупация Сербии Австро-Венгрией и борьба сербского народа за свое освобождение в 1916 - 1918 гг. C. 35 .

${ }^{38}$ Влахов T. Указ. соч. С. 247.

39 Југославија по вольи народа. 1914 - 1918. Фотомонография. Нови Сад, 1988. С. 192.
} 
уничтожил все балканские народы» ${ }^{40}$. Болгарский оккупационный режим в Сербии отличался антигуманным отношением к местным жителям и нарушал целый ряд пунктов Гаагской конвенции: депортация и интернирование, уничтожение культурных ценностей. Подобные меры имеют аналогию в деятельности тоталитарных и авторитарных режимов европейских стран в 1930 - 1940-е гг.

Изложенные выше факты опровергают мнение ряда болгарских историков о том, что, вступая в войну, Болгария поставила перед собой определенные национальные и освободительные, а не грабительские и завоевательные цели ${ }^{41}$. Вместе с тем, политика насильственной болгаризации Македонии явилась продолжением политики сербизации, проходившей перед этим. Фактически Сербия и Болгария пользовались одинаковыми методами ради достижения в общем-то схожей цели: закрепления македонского края в своем составе. И если в период сербского контроля македонцы выступали против сербских методов, то во время господства болгарской администрации их протесты были не менее активными.

\section{Библиография:}

1. Влахов Т. Отношенията между България и Централните сили по време на войните 1912 - 1918 г. София, 1957.

2. Гринберг С.Ш. Первая мировая война и болгарский народ / Исторические записки. Т. 21. М., 1947.

3. Дамянов С. България във френската политика (1878 - 1918). София, 1985

4. Дневници (стенографски) на XVII-то обыкновенно народно собрание. Втора рядовна сесия. Открыта на 14 декемврий 1915 г., закрыта на 15 марта 1916 г. София, 1928.

5. Зайончковский А.М. Первая мировая война. М., 2002.

${ }^{40}$ Коларов В. Мы, болгарские коммунисты, сегодня более, чем когда-либо признаем право на самоопределение разорванного на части македонского народа / Историческая правда. Прогрессивная общественность в Болгарии и Пиринской Македонии о македонском национальном вопросе. Документы, статьи, резолюции, призывы и публицистические труды. 1856 - 1956. Скопье, 1983. С. 69.

${ }^{41}$ См., например: Дамянов С. България във френската политика $(1878-1918)$. София, 1985. С. 38.
6. История македонского народа. Скопье, 1986.

7. История Югославии. М., 1963. Т. 1.

8. Коларов В. Мы, болгарские коммунисты, сегодня более, чем когда-либо признаем право на самоопределение разорванного на части македонского народа / Историческая правда. Прогрессивная общественность в Болгарии и Пиринской Македонии о македонском национальном вопросе. Документы, статьи, резолюции, призывы и публицистические труды. 1856 - 1956. Скопье, 1983.

9. Корсун Н.Г. Балканский фронт мировой войны. 1914 - 1918. М., 1939.

10. Косик В.И. Гордиев узел Балкан / Македония: проблемы истории и культуры. М., 1999.

11. Марков Г. Балканы и «балканизация». Историческая судьба балканских народов в XX веке // Человек на Балканах в эпоху кризисов и этнополитических столкновений $\mathrm{XX}$ в. / Отв. ред. Г. Литаврин, Р. Гришина. М., 2002.

12. Международные отношения в эпоху империализма. Документы из архивов царского и Временного правительств. Серия 3. 1914 - 1918. Т. VI. Ч. 1. М.; Л., 1935.

13. Насильственное выселение жителей из оккупированных областей Сербии. Одесса, 1917.

14. Терзиев В. Българският характер на славянскато население в Македония. София, 1995.

15. Писарев Ю. А. Оккупация Сербии Австро-Венгрией и борьба сербского народа за свое освобождение в 1916 - 1918 гг. // Советское славяноведение. 1965 . № 4.

16. Погодин А. Л. Русская политика на Ближнем Востоке, чем она была и чем должна бы быть / История Великой войны. Т. 1. М., 1915.

17. Подполковник Лярше. Некоторые статистические данные войны 1914-1918 гг. // Военный зарубежник. 1934. № 12.

18. Рид Д. Вдоль фронта (Война на Восточном фронте). М.; Л., 1928.

19. Сазонов С. Д. Воспоминания. М., 1991.

20. Сербия и Черногория. М., 1914.

21. Сербия под врагом. Официальные документы и нота сербского правительства. Одесса, 1917.

22. Шкундин Г.Д. Динамика болгарских военно-политических целей в ходе Первой мировой войны / Первая мировая война и проблемы политического переустройства в Центральной и Юго-Восточной Европе. М, 1991. 


\section{Политика и общество $5(101) \cdot 2013$}

23. Ястребов Н. В. Славянская сторона Великой войны 1914 - 1915 гг. / История Великой войны. М., 1915. T. 2.

24. Југославија по вольи народа. 1914 - 1918. Фотомонография. Нови Сад, 1988.

\section{References (transliteration):}

1. Vlakhov T. Otnosheniyata mezhdu B'lgariya i Tsentralnite sili po vreme na voynite $1912-1918$ g. Sofiya, 1957.

2. Grinberg S.Sh. Pervaya mirovaya voyna i bolgarskiy narod / Istoricheskie zapiski. T. 21. M., 1947.

3. Damyanov S. B'lgariya v'v frenskata politika (1878 - 1918). Sofiya, 1985

4. Zayonchkovskiy A.M. Pervaya mirovaya voyna. M., 2002.

5. Istoriya makedonskogo naroda. Skop'e, 1986.

6. Istoriya Yugoslavii. M., 1963. T. 1.

7. Kolarov V. My, bolgarskie kommunisty, segodnya bolee, chem kogda-libo priznaem pravo na samoopredelenie razorvannogo na chasti makedonskogo naroda / Istoricheskaya pravda. Progressivnaya obshchestvennost' v Bolgarii i Pirinskoy Makedonii o makedonskom natsional'nom voprose. Dokumenty, stat'i, rezolyutsii, prizyvy i publitsisticheskie trudy. 1856 - 1956. Skop'e, 1983.

8. Korsun N.G. Balkanskiy front mirovoy voyny. 1914 - 1918. M., 1939.

9. Kosik V.I. Gordiev uzel Balkan / Makedoniya: problemy istorii i kul'tury. M., 1999.

10. Markov G. Balkany i «balkanizatsiya». Istoricheskaya sud'ba balkanskikh narodov v XX veke // Chelovek na Balkanakh v epokhu krizisov i etnop- oliticheskikh stolknoveniy XX v. / Otv. red. G. Litavrin, R. Grishina. M., 2002.

11. Mezhdunarodnye otnosheniya $\mathrm{v}$ epokhu imperializma. Dokumenty iz arkhivov tsarskogo i Vremennogo pravitel'stv. Seriya 3. 1914 - 1918. T. VI. Ch. 1. M.; L., 1935.

12. Nasil'stvennoe vyselenie zhiteley iz okkupirovannykh oblastey Serbii. Odessa, 1917.

13. Terziev V. B'lgarskiyat kharakter na slavyanskato naselenie v Makedoniya. Sofiya, 1995.

14. Pisarev Yu. A. Okkupatsiya Serbii Avstro-Vengriey i bor'ba serbskogo naroda za svoe osvobozhdenie v 1916 - 1918 gg. // Sovetskoe slavyanovedenie. 1965. № 4.

15. Pogodin A. L. Russkaya politika na Blizhnem Vostoke, chem ona byla i chem dolzhna by byt' / Istoriya Velikoy voyny. T. 1. M., 1915.

16. Podpolkovnik Lyarshe. Nekotorye statisticheskie dannye voyny 1914-1918 gg. // Voennyy zarubezhnik. 1934. № 12 .

17. Rid D. Vdol' fronta (Voyna na Vostochnom fronte). M.; L., 1928.

18. Sazonov S. D. Vospominaniya. M., 1991.

19. Serbiya i Chernogoriya. M., 1914.

20. Serbiya pod vragom. Ofitsial'nye dokumenty i nota serbskogo pravitel'stva. Odessa, 1917.

21. Shkundin G.D. Dinamika bolgarskikh voennopoliticheskikh tseley v khode Pervoy mirovoy voyny / Pervaya mirovaya voyna i problemy politicheskogo pereustroystva v Tsentral'noy i Yugo-Vostochnoy Evrope. M, 1991.

22. Yastrebov N. V. Slavyanskaya storona Velikoy voyny 1914 - 1915 gg. / Istoriya Velikoy voyny. M., 1915. T. 2.

23. Jugoslavija po vol'i naroda. 1914 - 1918. Fotomonografiya. Novi Sad, 1988. 